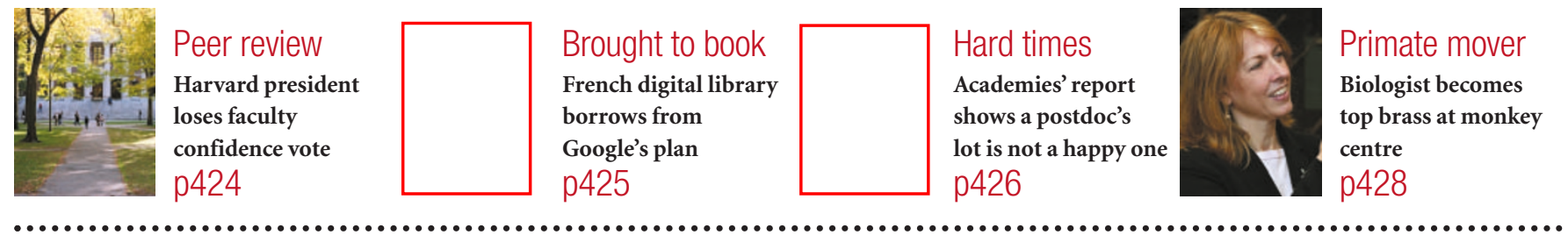

\title{
US launches probe into sales of unapproved transgenic corn
}

\section{Colin Macilwain, Washington}

A strain of genetically modified corn that does not have regulatory approval has been distributed by accident over the past four years, Nature has learned.

Syngenta, one of the world's largest agricultural biotechnology companies, revealed the mistake to US regulators at the end of last year. Although the crop is believed to be safe, the fact that it was sold for years by accident raises serious questions about how carefully biotechnology firms are controlling their activities, critics say.

The corn (maize) was modified with a gene from the soil bacterium Bacillus thuringiensis $(B t)$, which is inserted into the crop to act as a pesticide. Syngenta has approval to sell a variety of the transgenic crop called $B t 11$, which has been used successfully for many years in the United States and elsewhere. The strain has been approved for consumption in the European Union, for example, and may be one of the first food crops approved for cultivation there.

But between 2001 and 2004, Syngenta inadvertently produced and distributed several hundred tonnes of $B t 10$ corn - a different genetic modification that has not been approved.

Since the release was discovered in late 2004, US government scientists have assessed the $B t 10$ corn - which differs from $B t 11$ by only a handful of nucleotides on a section of the gene that does not code for the protein toxin - and have concluded that it is safe to eat and poses no environmental threat.

"What makes this somewhat unique is that $B t 10$ and $B t 11$ are physically identical and the proteins are identical," says Jeff Stein, head of regulatory affairs at Syngenta in Research Triangle Park, North Carolina.

Sarah Hull, a spokeswoman for the company in Washington DC, adds that Syngenta promptly reported the mistake to regulators after the discovery. She says this shows that the system is working as it should do. Company officials also note that the release was relatively small. About 150 square kilometres of the crop was planted over the four years,

\section{IMAGE UNAVAILABLE FOR COPYRIGHT REASONS}

Seeds of doubt: critics say release of the wrong form of corn shows more regulation is needed.

they say, which is $0.01 \%$ of all corn planted in the United States during that period. As Bt corn seed has to be bought every year, rather than being gathered from the previous year's crop, the problem should not escalate.

\section{Hard to swallow}

But Michael Rodemeyer, director of the Pew Initiative on Food and Biotechnology, a think-tank in Washington DC, says that the release reflects the absence of a thorough monitoring system for genetically modified products in the US food supply. "This will raise questions in the minds of countries that import food from the United States about whether we have adequate controls in place," Rodemeyer says. "It will provide ammunition for critics of genetically modified food - and it may provide incentives for countries to look at non-genetically modified varieties."
Syngenta discovered the mistake when one of its seed manufacturers, which was attempting to use the corn seeds in plantbreeding experiments, informed it that the seed was not $B t 11$.

Syngenta then told the Environmental Protection Agency (EPA), the Food and Drug Administration and the US Department of Agriculture (USDA), which are jointly responsible for approving genetically modified crops. Regulators and the company have since been involved in months of discussions over what should be done about the error, and how and when information should be released to the public.

White House officials have also been involved in these sensitive talks, partly because the United States and the European Union are locked in a fierce trade dispute over whether tough European rules to trace the flow of genetically modified crops are scientifically necessary. Syngenta officials declined to list the countries that accidentally received the $B t 10$ seed.

In a statement released to Nature on 14 March, the EPA says that regulatory agencies are "conducting investigations to determine the circumstances surrounding and extent of any violations of relevant laws and regulations". The EPA says that it is investigating whether the Federal Insecticide, Fungicide, and Rodenticide Act has been breached, and that the USDA is looking at possible violations of the Plant Protection Act. "The US government is also communicating with our major trading partners to ensure they understand there are no food safety or environmental concerns," it adds.

The last major, unintended release of a genetically modified crop in the United States occurred in 2000, when a Bt corn known as StarLink was inadvertently planted for human consumption. Because of possible allergic reactions, StarLink had been approved for use only in animal feed. Recall of StarLink corn cost the food industry an estimated US\$1 billion, according to Rodemeyer, and lent impetus to global concerns about the safety of genetically modified food. 